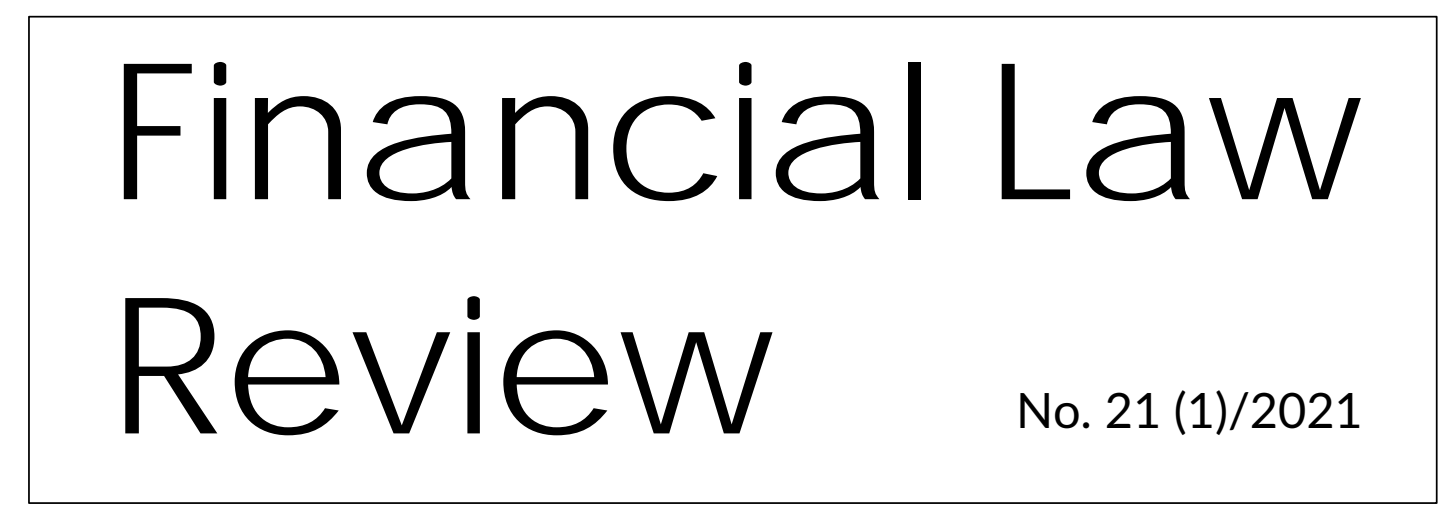

UNIVERSITY OF GDAŃSK • MASARYK UNIVERSITY • PAVEL JOZEF ŠAFÁRIK UNIVERSITY • UNIVERSITY OF VORONEZH http://www.ejoumals.eu/FLR

\title{
IMPLEMENTATION OF DIRECTIVE 2011/61/EU OF THE EUROPEAN PARLIAMENT AND OF THE COUNCIL OF 8 JUNE 2011 ON ALTERNATIVE INVESTMENT FUND MANAGERS INTO CZECH LEGAL SYSTEM
}

\begin{abstract}
This contribution deals with the implementation of Directive 2011/61/EU of the European Parliament and of the Council of 8 June 2011 on Alternative Investment Fund Managers and amending Directives 2003/41/EC and 2009/65/EC and Regulations (EC) No 1060/2009 and (EU) No 1095/2010 into Czech legal system. The main aim of the contribution is to confirm or disprove the hypothesis that entity in Section 15 of Act no. 240/2013 Coll, on Investment Companies and Investment Funds, as amended, is an alternative fund according to the Directive 2011/61/EU and that Directive 2011/61/EU was not transposed in Czech Republic properly. Author used to confirm or disprove above mentioned hypothesis scientific methods, especially comparison, induction and deduction. This contribution also looks at the Directive 2011/61/EU evaluation of its effectiveness and possible development of regulation in this area.
\end{abstract}

Key words: Alternative Investment Fund, Investment fund, Underhand Retail Investment Fund, Implementation, Management of assets comparable to the management of Investment Funds.

JEL Classification: K33

* Doctoral student, Department of Financial Law and Economics, Faculty of Law, Masaryk University, Brno, Czech republic. Also associate in Law Office specializing in financial market. Author specializes in payment services providers, bonds and investment funds. Contact e-mail: Zuzana.Sikova@law.muni.cz, https://orcid.org/0000-0002-6808-0196. 


\section{Introduction}

Directive 2011/61/EU of the European Parliament and of the Council of 8 June 2011 on Alternative Investment Fund Managers and amending Directives 2003/41/EC and 2009/65/EC and Regulations (EC) No 1060/2009 and (EU) No 1095/2010 (hereafter referred to as "AIFMD") regulates the general legal framework applicable to alternative investment fund managers. The aim of the Directive can be found in the AIFMD recital, which aims to provide for an internal market for AIFMs and a harmonized and stringent regulatory and supervisory framework for the activities within the Union of all AIFMs, including those which have their registered office in a Member State (EU AIFMs) and those which have their registered office in a third country (non-EU AIFMs) [Directive 2011/61/EU, Recital]. Here it is necessary to focus on the fact that all the AIFMD is focused only on the rights and obligations of the fund managers, and therefore not the very essence of AIFs that are subject to self-regulation at a national level. The aim is set very general, but from the recital of the Directive, AIFMD can be judged on a broad view of the issue of investment funds and alternative investment funds, when these entities on the financial market preoccupied with an increasingly larger proportion in the case of improper settings of powers managers could to disrupt it, especially through the high risk that is placed on investors in these funds. The main stated objective of the AIFMD is to ensure better supervision of systemic risks arising from the economic power that some investment funds may pose through more sophisticated regulation in areas that are not yet harmonized at European Union level [Act No. 240/2013 Coll, on Investment Companies and Investment Funds, Explanatory Memorandum]. In summary, the purpose of this regulation is to cover non-harmonized entities that perform similar activities as a collective investment, but are not affected by the regulation of standard collective investment funds (i.e. UCITS funds). AIFMD brings many opportunities, such as expanding the European market for alternative funds and reducing the supply and demand for investing in nonAIFs. The risk arising from the AIFMD can be described as the growing concentration of financial centres and the outflow of Czech capital abroad [Act No. 240/2013 Coll, on Investment Companies and Investment Funds, Explanatory Memorandum]. Of course, the development of entities that are not affected by the AIFMD can also be identified as a risk. Due the fact that the AIFMD has been in force since 2013, there is still a great diversity of legal regimes governing non-AIFs, and unregulated areas remain in the European field, as stated by Doležalová in her contribution to the AIFMD speech in 2010 [Doležalová 2010: 212]. 
This contribution through further view on directives, secondary sources from European Securities and Markets Authority (hereinafter referred to as "ESMA"), reports from the Commission, shall examine how the AIFMD was transposed to Czech legal system, and what consequences the AIFMD caused in the Czech Republic, and confirm or disprove hypothesis that entity in Section 15 of Act no. 240/2013 Coll, on Investment Companies and Investment Funds, as amended (hereinafter referred to as "ZISIF") is an alternative fund according to the Directive 2011/61/EU and that Directive 2011/61/EU was not transposed in Czech Republic properly, based on comparison, induction and deduction.

\section{Why AIFMD exists?}

If we want to answer the question of what the AIFDM Directive is, it can certainly be started by saying that it is an act of the European Union with the aim to harmonize a part of a certain type of fund that has not been regulated by another act of the European Union. The AIFMD, therefore, targets the area of financial market managers, which raise capital from investors to invest common capital and thus generate revenue. Here we can see a certain connection with collective investment funds in the Czech legal system, respectively with Section 93 ZISIF, according to which the purpose of a collective investment fund is to raise funds from the public for the purpose of a common investment strategy for investors [Act No. 240/2013 Coll, on Investment Companies and Investment funds, Art. 93]. Collective investment itself is defined as a business activity whose objective is to raise funds by subscribing to shares of an investment fund or by issuing unit certificates of a mutual fund, investing in the principle of risk spreading and further management of these assets [see Section 2 par. 1 let. a) Kollnv ${ }^{1}$ ]. Collective investment may be performed by investment companies and investment funds (A similar activity exercised in the management of the resources entrusted to pension funds) [Štenglová 2009]. However, collective investment funds have their own harmonizing legal framework, in particular the Directive 2009/65/EC of the European Parliament and of the Council of 23 July 2009 on the coordination of laws, regulations and administrative provisions relating to undertakings for collective investment in transferable securities (UCITS) (hereinafter referred to as the "UCITS IV Directive").

Then what is the difference between the regulation of collective investment and alternative investment funds, where according to the basic definition we can talk about

\footnotetext{
${ }^{1}$ Act No. 189/2004 Coll., on Collective Investment, hereinafter referred to as "ZKI", was replaced by the effectiveness of ZISIF.
} 
similar activities? The main differences include different investment strategies and target investors for whom the funds are intended [Directive 2011/61/EU, Recital] [Act No. 240/2013 Coll, on Investment Companies and Investment Funds, Explanatory Memorandum]. And of course, different degree of harmonization.

If we return to the original question why the AIFMD exist, it is necessary to mention that among other motivations for harmonization this area and especially, to include as many entities as possible under AIF definition, historical scandals in the financial market, respectively scandals with hedge funds, were also height motivation. Hedge funds, which will usually be funds according to the AIFMD, are very risky and usually more than $70 \%$ of investors in hedge funds lose their invested capital. This was true in the case of Madoff's affair, when Madoff operated the fund under the Ponzi scheme [Doležalová 2013: 258]. Ponzi scheme is an investment fraud that pays existing investors with funds collected from new investors. Ponzi scheme organizers often promise to invest your money and generate high returns with little or no risk. But in many Ponzi schemes, the fraudsters do not invest the money. Instead, they use it to pay those who invested earlier and may keep some for themselves. [U. S. Securities and exchange commission, Ponzi Scheme]. It was the Ponzi scheme that was one of the AIFMD's motivations for the responsibility AIF managers to that this investment under Ponzi scheme did not take place. However, investing under the Ponzi scheme can be seen very often in Czech Republic, and especially in the case of the entity of Section 15 ZISIF, as it is not a regulated entity, as will be discussed below, the Ponzi scheme can be traced very often.

\section{AIFMD is gaining place in the Czech legal system}

The AIFMD was adopted on 8 July 2011 and, according to Article 70 of the AIFMD, entered into force on the twentieth day following that of its publication in the Official Journal of the European Union on the 21 July 2011. The Member States, the Czech Republic including, were required to implement transposition of the AIFMD by 22 July $2013^{2}$ and to communicate to the Commission the text of the adopted and published laws, regulations and administrative provisions necessary to achieve compliance, incl. correlation tables [Directive 2011/61/EU, Art. 66]. Unfortunately, the author was unable to trace this documentation provided to the Commission.

Implementation of the AIFMD incl. the transposition of the UCITS IV Directive and the proposal for a Directive of the European Parliament and the Council amending UCITS IV

\footnotetext{
${ }^{2}$ One-year transitional period ended on $22^{\text {nd }}$ July 2014.
} 
(hereinafter "UCITS V") resulted in the transposition of the Directives into one Act, namely Act No. 240/2013 Coll., on Investment Companies and Investment funds, which replaces ZKI.

The transposition of the AIFMD has significantly affected the content of the ZISIF, with only marginal mention of the transposition of Article 6 (4) of the AIFMD by the possibility of exceeding the relevant limit for certain investment services, thus, increasing flexibility regarding the extended range of managed fund types. The content of the provisions of Section 15 ZISIF appears closest to the AIFMD Directive. This paper focuses mainly on the transposition of AIFMD into ZISIF in comparison with Section 15 ZISIF, and therefore will not deal further with individual aspects of transposition and influence of investment companies and investment funds.

When we talk about the transposition of AIFMD into the Czech legal system, we talk about alternative funds in addition to investment funds. The designation of the investment fund may be used only by entities that are an investment fund according to ZISIF, resp. according to Section 92 ZISIF, which is a collective investment fund or a fund of qualified investors, and are therefore subject to the formal scrutiny of the Czech National Bank. Otherwise, it would be a underhand retail investment fund, which is defined in Section 98 ZISIF, according to which is prohibited to collect, as well as to attempt to collect, financial means or things whose value can be expressed in monetary terms from the public for the purpose of joint investing them or investing of thus acquired financial means or things whose value can be expressed in monetary terms, if the return of an investment or profit of an investor is to be, even if partially, dependent on the value or revenue of the assets in which the financial means or things whose value can be expressed in monetary terms, that have been invested under conditions other than those provided for or allowed by this Act [Act No. 240/2013 Coll, on Investment Companies and Investment Funds, Art. 98] . This means that an entity may use the designation (investment) fund only if it is a self-managed investment fund or an investment fund managed by an investment company. Otherwise, this designation cannot be used. If we were already looking for a comparison with alternative funds, this alternative fund would be a fund that is not an investment fund or an underhand retail investment fund according to ZISIF. However, such funds have no place or legal definition in the Czech legal system. The only indication can be found in the subject under Section 15 ZISIF as the management of assets comparable to the management of investment funds, which, however, is also subject to the prohibition of the underhand retail investment fund, respectively according to Section 98 par. 4. ZISIF, which, however, may not use the designation "fund". 
For a deeper perspective on the regulation of AIFMD and Section 15 ZISIF, it is first necessary to look separately at the amendment of Section 15 ZISIF and its position on the Czech financial market. According to the provisions of Section 15 ZISIF, as amended from 1 May 2020, this is asset management comparable to the management of investment funds, which is defined as a legal person who is not authorised to manage investment funds, and who, in the Czech Republic manages or intends to manage assets under a trading licence or a similar way, for the purpose of earning income, consisting in collecting financial means or things whose value can be expressed in monetary terms from investors, or acquired in exchange for such financial means or things whose value can be expressed in monetary terms, for the purpose of collective investment on the basis of a defined strategy for the benefit of these investors, must submit an application for registration in a register kept by the CNB according to Section 596 (f) and be registered in this register [Act No. 240/2013 Coll, on Investment Companies and Investment Funds, Art. 15]. The first sentence does not apply to the assets management of an investment fund. A person registered in the register maintained by the CNB according to Section 596 (f) ZISIF is not authorised to exceed the relevant threshold [Act No. 240/2013 Coll, on Investment Companies and Investment Funds, Art. 15].

The provision of Section 15 ZISIF has undergone a major change since the effectiveness of ZISIF, namely the definition of a subject who can perform asset management comparable to management, when the entity was previously defined as "the one", i.e. it was both a natural person and a legal entity, in this case even a person without legal personality. In this case the requirement for an entity subject of Section 15 ZISIF was tightened [Act No. 240/2013 Coll, on Investment Companies and Investment Funds, Art. 15]. The entry in the list maintained by the Czech National Bank then aims to simplify the regime for the administrator of the entity of Section 15 ZISIF, because they do not reach an unbearable level of systemic risk due to a smaller volume, i.e. in case the decisive limit is not exceeded. This registration is not subject to the administrative discretion of the Czech National Bank, and the Czech National Bank is not entitled to review any documents provided to it at the time of application for registration. It is necessary to register before the actual start of the activities of entities of Section 15 ZISIF [Czech National Bank, Asset management comparable with the management (Section 15 ZISIF)].

Concerning the amendment to ZISIF, a formalistic error occurred, when the provision of $\S$ 596 letter e) ZISIF, and thus the reference both original and existing in Section 15 par. 1 ZISIF (which has not been changed in this respect) to the entry in the list according to $\S$ 596 letter $\mathrm{f}$ ) is no longer, in fact, possible and becomes non-functional, because according 
to the effective state as of 31 August 2020, the provisions of $\S 566$ letter $f$ ) refers to the list of persons who may be appointed as a liquidator of a management company, a retail investment fund with a legal personality and a main administrator [Act No. 240/2013 Coll, on Investment Companies and Investment Funds, Art. 596] and no longer to entities of Section 15 ZISIF. ZISIF contains several similar inaccuracies, and from a strictly formalistic point of view, all these provisions become non-functional. That means, that all these provision in ZISIF would not be applicable, and thus it would be obscure that the entities of Section 15 ZISIF are not obligated to entry in the list under $\S 596$ letter e) ZISIF and the Czech National Bank would thereof have no discretion to supervise these entities. Here it is necessary to think about the meaning of the legislator, and use $\S 596$ letter e) ZISIF even if the law does not directly refer to it.

From the above it is now possible to state the definition of entity of Section 15 ZISIF as (i) a legal entity that does not have authorization from the Czech National Bank to manage an investment fund, (ii) manages or intends to manage assets on the basis of trade license or similar authorization, (iii) collects from investors funds or valuables, (iv) for the purpose of joint investment, (v) on the basis of a joint strategy, (vi) for the benefit of these investors, (vii) submits an application for registration in the list maintained by the Czech National Bank and is on this list conducted during the period of activity, (viii) does not exceed the decisive limit. However, asset management comparable to management is almost identical to the definition of a collective investment fund. The definition of a collective investment fund can be defined positively as (i) one, (ii) one who collects or attempts to raise money or money valuables, (iv) for the purpose of joint investment, $(v)$ and the return on investment depends on the assets, which funds are invested. It follows from the negative definition of Section 98 para. 2 that it is not a mortgage fund, and therefore (i) one (ii) who otherwise meets the definition of a mortgage fund acts in accordance with the law if it collects funds from qualified investors or from the public.

Doesn't the so-called "hedge" fund appear here ${ }^{3}$ alternatively, the option for an unadjusted AIFMD framework? Let's go back to the comparison of the institute of Section 15 ZISIF and the underhand retail investment fund. The only difference here is that the institute of Section 15 ZISIF can be carried out only if it does not collect funds from the public (here the very key term "public") and the return / profit of the funds collected does not depend on the value of assets in which these funds were invested.

\footnotetext{
${ }^{3}$ Hedge funds are considered one of the types of AIF according to the consultation material of the Ministry of Finance. More In: Ministry of Finance, Transposition of the Directive on Administrative Alternative Investment Funds. Consultation material, 2011.
} 
An indirect definition of the term public can be found in Section 295a ZISIF, which speaks generally of public marketing and non-public offering (private placement), namely marketing an investment in an investment fund or a foreign investment fund in the Czech Republic to those who are not qualified investors, other than publicly (private placement), can only be marketed if such investments in the Czech Republic can be marketed publicly or the number of such persons does not exceed 20 [Act No. 240/2013 Coll, on Investment Companies and Investment Funds, Art. 295a]. This provision does not directly target the entities of $\S 15 \mathrm{ZISIF}$, as it is not an investment fund, this criterion should only be of a supportive nature. However, it is clear from the information of the Czech National Bank of 23 April 2018 that the Czech National Bank is in favour of the number of 20 persons as a definition of the public, based on its statement, according to which it states that it is however unlikely that the number of more than 20 people was linked to the beneficiary of such bonds, which would exclude their assessment as a wider range of people and therefore the public [Czech National Bank, The term "public" in the regulations on the financial market]. The Czech National Bank further explicitly states in this communication that it will follow this interpretation in any case, unless expressly stated otherwise by law. It follows from all the above that the entity of Section 15 ZISIF has similar opportunities for collective investment only if it does not reach more than 20 retail investors. Below we will look at whether this corresponds to the definition of an alternative fund according to the AIFMD. It can only be mentioned marginally that as of 31 August 2020, 221 entities listed in 15 ZISIF are listed in the Czech National Bank [Czech National Bank, List and records of regulated entities on the financial market].

\section{Alternative investment fund = Entity of Section 15 ZISIF?}

Before moving on to the comparison itself, it is very important to focus on the key concept of AIF, which, for example, the Ministry of Finance in its consultation material on AIFM, for the same reason as the consultation material states that this is because, at the moment when it can be said that a certain entity or other legal institution meets the characteristics of an AIF under the Directive, it can and must be managed only by a manager who meets the requirements of the Directive [Ministry of Finance, Transposition of the Directive on Alternative Fund Managers]. So how is an alternative fund defined according to the AIFMD?

The definition of an AIF is given in Article 4 of the AIFMD, which for the purposes of the AIFMD means an AIF a subject of collective investment, which: i) raises capital from a 
number of investors to invest in accordance with a particular investment policy in favor of those investors, (ii) is not required to obtain an authorization in accordance with Article 5 of Directive 2009/65/ES [Directive 2011/61/EU, Art. 4]. The term AIF (also referred to as "AIF" or "AlFs") must be interpreted jointly, uniformly, and consistently. Among other things, the General Guidelines on Key Concepts of the Directive on Alternative Investment Fund Managers, ESMA / 2013/611 of 13 August 2011 (hereinafter referred to as the "ESMA Guidelines") serve to do so. According to the ESMA Guidelines, they are AIF if they have all of the following characteristics, namely (i) a collective investment undertaking, (ii) the raising of capital, (iii) numerous of investors, (iv) a certain investment policy.

A collective investment undertaking is then defined as an entity which has no general commercial or industrial purpose, pools capital from investors [...] in order to generate pooled returns for these investors, unit holders or shareholders of the company (as a collective group) do not have discretion or controls relating to day-to-day matters [ESMA/2013/611, Guidelines, 2011]. Compliance with the entity of Section 15 ZISIF can already be seen here, where a legal entity that wants to perform management comparable to management usually acquires investors on the basis of unit holdings, even if these investors do not have to project into the ownership structure of the legal entity (e.g. SICAV), although their investment strategy does not have to be based on pooled return, because if capital is raised on a contractual basis, the pooled return criterion does not need to be met, and everything moves on the basis of contractual arrangements between the entity of Section 15 ZISIF and the individual investor, even on the basis of a common investment strategy, but this is usually the case. This character is largely filled.

The raising capital is defined as the business of conducting direct or indirect action by the firm or person or entity acting on behalf of the company [...] to ensure the transfer or custody of funds from one or more investors undertaking for the purpose of investing this capital [...] [ESMA/2013/611, Guidelines, 2011]. The above definition certainly applies to the activities of the institute Section 15 ZISIF, and therefore it can be said that it fulfils the above-mentioned character of the AIF.

The definition of another character of an AIF, as an entity acquiring a larger number of investors, is slightly clumsily defined according to the general guidelines, as an undertaking which is not prevented by its national law, the rules or instruments of incorporation, or any other provision or arrangement of binding legal effect, from raising capital from more than one investor should be regarded as an undertaking which raises capital from a number of investors in accordance with Article 4(1)(a)(i) of the AIFMD. This should be the case even if it has in fact only one investor [ESMA/2013/611, Guidelines, 2011]. In this case it means 
that national legislation does not prevent the raising of capital. It follows that the Czech legal system allows an entity to raise capital from more than one investor, if it is entered in the relevant list maintained by the Czech National Bank, also if the public is not reached and the decisive limit is not exceeded.

If we turn slightly to how the number of investors was previously attributed, the following can be said. Many articles have been written about the AIFMD, AIFs or managers of AIFs in the Czech Republic, which are almost identical in their view and interpretation to the regulation of this area. Let`s get look, for example, at the article by Králík from 2011 in the Commercial Law Review 20/2011, whether its conclusions can still be applied with regard to the new Czech regulation, resp. ZISIF. Article by Králík first deal with the aim of adjusting the AIFMD and the definition of an alternative investment fund. We will stop at this area. In the case of the definition, article by Králík states that the key term of AIF is "large number of investors", which based on Czech case law, list at least 7 investors, but it is not decisive in this regard and it is necessary to base this term under European acts. Based on ESMA Guidelines, a number is determined to be greater than one, and therefore the threshold set by Králík cannot be used in this case anymore. Králík further states that with regard to the $\mathrm{ZKI}$ and the Prospectus Directive (as of the date of this contribution, Regulation (EU) 2017/1129 of the European Parliament and of the Council of 14 June 2017 on the prospectus to be published when securities are offered to the public or admitted to trading on a regulated market, and repealing Directive 2003/71/EC (hereinafter referred to as "Regulation of Prospectus")), if the definition of the public should be at the level of 150 persons, the funds of qualified investors would not fall within the scope of the AIFMD. In this case and with regard to the development of the Czech legal system, this conclusion can no longer be applied, as qualified investor funds are subjects to the UCITS IV Directive and this reason cannot be used to argue why a qualified investor fund cannot be subordinated to an AIFMD. Králík also states that the AIFMD Directive no less targets funds that are not offered to the public and are offered to professional (qualified) investors. Based on the above, it could be said that from the point of view of the Czech legal system, the AIFMD primarily targets to entities of Section 15 ZISIF. Králík also makes an important point with regard to the administrator, according to which a natural person cannot managed AIF [Králík 2011: 303]. This finding is (was) very beneficial, although now irrelevant, as ZISIF explicitly regulated in effect until 12 August 2017 that the administrator of the $\S 15$ ZISIF entity may be both a legal entity and a natural person. Thus, the AIFMD was not properly reflected in the Czech legal system until the amendment with effect from 13 August 2017. Until then, it was not possible to speak 
of the entity of Section 15 ZISIF as an alternative fund according to the AIFMD. Králík also mentions the scope regarding investment companies in the Czech Republic, but with regard to ZISIF and the UCITS regulations, some of its conclusions can no longer be used.

The last character that subject shall considered to fulfil the AIF is a certain investment policy. According to the ESMA Guidelines, this feature should, at least on its own, pursue a policy that is (i) determined and fixed; (ii) in a document that is binding on the enterprise, (iii) the managing entity has an obligation to comply with this policy and is enforceable by investors, (iv) contains investment guidelines such as investing in a particular asset category, targeted investment in particular geographical area areas, specific risk diversification [ESMA/2013/611, Guidelines, 2011].

It follows from all the above that the entity in Section 15 ZISIF is usually an alternative fund according to the AIFMD, which is covered by an exception under Article 3 (2). This means that the entity of Section 15 ZISIF is an alternative fund according to the AIFMD, but in the Czech legal system with regard to terminology refers to management comparable to management, where this entity may not use the term "fund" in its name.

According to the explanatory memorandum to the provisions of Section 15 ZISIF, it is stated that Section 15 itself is a transposition of the AIFMD directive, incl. provisions of Section 17, Section 477, Section 480, Section 513, Section 533, Section 596, Section 616 para. 5, Section 620 para. 5, Section 637, Section 646 para. 2, Section 662 para. 3) ZISIF. Furthermore, it is possible to see, at least marginally, whether the Directive is transposed with regard to the use of the opt-in regime based on the Article 3 (4) of the AIFMD and in accordance with Commission Implementing Regulation (EU) No 447/2013 of 15.5. 2013 laying down the procedure for AIFM who decide to be covered by Directive 2011/61 / EU of the European Parliament and of the Council (hereinafter the "Opt-in Regulation").

If this were the case, then the entity of Section 15 ZISIF could be subject to the benefits of AIFMD, which were transposed into ZISIF, according to the Opt-in Regulation and in accordance with the provision of ZISIF. What can be found using the opt-in is not clear, ZISIF states in this regard only in the provision of Section 533 paragraph 2, according to which the proving of the fulfilment of prerequisites laid down by this Act with respect to the decision on application for authorisation authorising to exceed the relevant threshold, if a legal person according to Section 15 applies for it, is defined in Article 1 of Commission Implementing Regulation (EU) No 447/2013 [Act No. 240/2013 Coll, on Investment Companies and Investment funds, Art. 533] . It follows that if the entity of Section 15 ZISIF used opt-in regime under the Opt-in Regulation, it would submit an application under the 
AIFMD, to which the Opt-in Regulation refers, would be subject to the AIFMD, which, however, is not self-executing as a directive and therefore, it is not entirely clear what consequences this opt-in would bring in the Czech legal system.

According to the explanatory memorandum to the ZISIF, the possibility of voluntary opt-in to the AIFMD regime is clearly mentioned, where the main advantage is the acquisition of a European passport. In the case of the use of opt-in to the AIFMD, we continue to get to Regulation (EU) No. 346/2013 of the European Parliament and of the Council of 17 April 2013 on European social entrepreneurship funds (hereinafter referred to as "Regulation EUSEF") and Regulation (EU) No. 345/2013 of the European Parliament and of the Council of 17 April 2013 on European venture capital funds (hereinafter referred to as "Regulation EUVECA"). However, these regulations do not apply to retail investors [Regulations $345 / 2013$ and 346/2013, Recitals], and based on nature of Section 15 ZISIF is a disproportionate burden, when these funds are offered to a maximum of 20 investors. If entities would use opt-in under AIFMD, its can choose, it its undertake all right and obligations under AIFMD, or under Regulation EuSEF, Regulation EuVECA, or use national regime of the Czech Republic and initiate licensing proceedings for the management of investment funds. That basically means, that when entity of Section 15 ZISIF uses the national regime of Czech Republic for opt-in, it loses the position of the alternative investment fund according to AIFMD and becomes the manager of investment fund. This above mentioned suggests that AIFMD has not been properly implemented here. Only marginally we can mention that if entities use opt-in regime based on AIFMD to Regulations EuSEF a EuVECA, it should be probably very complicated according the fact, that managers should register in competent authorities twice - based on AIFMD and based on Regulations EuSEF and EuVECA. ESMA comments on this issue of double registration as follows however, taking into account that the purpose of the EuSEF and EuVECA Regulations is to create a light regime that facilitates the cross-border activity of these managers, the double registrations could take place simultaneously. National competent authorities are invited to simplify this process in order to avoid unnecessary repetition in the registration process [Application of the EuSEF and EuVECA Regulations, ESMA/2016/774]. In the author's opinion, the Czech legal system is not prepared for regulation either according to AIFMD or according to Regulation EuSEF or Regulation EUVECA. 


\section{Future of AIFMD as AIFMD II?}

It has been over 7 years that AIFMD has been effective. Therefore, the fundamental question is how the area with alternative funds will develop. An indication of the development can be seen in Article 69 of the AIFMD, according to which the Commission is obliged to review the application of the AIFMD, incl. the very impact of harmonizing the area with AIFs. This review was launched in 2018 and the last review was carried out on 10 June 2020. From a report from the Commission to the European Parliament and the Council, Brussels 10. 6. 2020, COM (2020) 232, about assessing the application and the scope of Directive 2011/61/EU of the European Parliament and of the Council on Alternative Investment Fund Managers (hereinafter "Report 2020") follows that the regulatory area will in the future focus on improving the interpretation of AIFMD, which brings a more limited scope to AIFMD, marketing rules for AIF, activation of AIFMD passport. The 2020 report further shows that the benefits of AIFMD have not yet been fully exploited and that financial market developments need to be monitored in the future in view of the growth of AIFM. Furthermore, Report 2020 proposes to reduce some of the barriers to AIFs exempted from AIFMD [COM (2020) 232, Report from the Commission]. Whether to expect AIFDM II is not yet entirely certain, as not all analyses leading to a major update of the AIFMD have been carried out so far, but it can be assumed that the report will lead to more debate on how to further harmonize the area.

\section{Conclusion}

This paper dealt with the transposition of the AIFMD and in particular the assessment of whether the entity of Section 15 ZISIF is an alternative fund according to the AIFMD. After a more detailed assessment, the author came to the conclusion that the entities of Section 15 ZISIF show almost identical features as an alternative fund according to AIFMD, but it can be said with certainty that even if we mark the entity Section 15 ZISIF as an alternative fund according to AIFMD use the terminological name "fund", as it is not a "fund" according to Czech law and the name according to AIFMD cannot be used in Czech law with regard to the fact that AIFMD is non-self-executing. It is also a very interesting view that although we mark the entity Section 15 ZISIF as an AIF according to the AIFMD, in the case of using the opt-in regime according to the Opt-in Regulation, the Czech legal system does not fully know the benefits of this opt-in and the real functioning of this options. AIFMD has not been properly implemented in opt-in area. However, only time will tell how it really works. We just have to wait for it. 


\section{References}

Doležalová D.: On the Proposal for a New Directive of the European Parliament and of the Council on Alternative Investment Fund Managers, Commercial and Legal Review 7/2010.

Doležalová D.: Some aspects of the delegation of depositary functions from the perspective of the AIFMD and the Implementing Regulation, Commercial and Legal Review 9/2013.

Králík A.: The scope of the new AIFMD, Commercial and Legal Review 10/2011.

Schall A., Kravets A.: Recent Capital Market Regulatory Developments in Germany and the EU. Korea Capital Market Institute. EU Financial Market Focus I, Spring 2014.

Štenglová I.: Collective investment (in:) HENDRYCH, D. (et al.), Právnický slovník [Law Dictionary]. 3rd ed., Prague: C.H. Beck, 2009

\section{Legal Acts}

Act No. 189/2004 Coll, on collective investment.

Act No. 240/2013 Coll., on Investment Companies and Investment Funds, as amended.

Act No. 240/2013 Coll., on Investment Companies and Investment Funds, effective from 19 August 2013 to 31 December 2014.

\section{Other Official Documents}

Commission Implementing Regulation (EU) No. 447/2013 of 15 May 2013 establishing the procedure for AIFMs which choose to opt in under Directive 2011/61/EU of the European Parliament and of the Council.

Available at:

https://www.beck-online.cz/bo/document-

view.seam?documentld=mv2tgxzsgaytgx3sga2diny\&grouplndex=0\&rowlndex=0, accessed: $31^{\text {st }}$ August 2020.

Directive 2011/61/EU of the European Parliament and of the Council of 8 June 2011 on Alternative Investment Fund Managers and amending Directives 2003/41/EC and 2009/65/EC and Regulations (EC) No 1060/2009 and (EU) No 1095/2010. Available at:

https://www.beck-online.cz/bo/document-view.seam?documentld=mv2tgxzsgaytcx3mgaydmmi, accessed: $31^{\text {st }}$ August 2020.

Directive 2009/65/EC of the European Parliament and of the Council of 13 July 2009 on the coordination of laws, regulations and administrative provisions relating to undertakings for collective investment in transferable securities (UCITS).

Available at:

https://www.beck-online.cz/bo/document-

view.seam?documentld=mv2tgxzsgaytcx3mgaydmmi, accessed: 31 ${ }^{\text {st }}$ August 2020.

European Securities and Markets Authority. Questions and Answers. Application of the EuSEF and EuVECA Regulations. ESMA/2016/774 on 31 May 2016,

Available at:

https://www.esma.europa.eu/sites/default/files/library/2016-774_qa_eusef-euveca.pdf, accessed: $31^{\text {st }}$ August 2020.

Explanatory Memorandum to Act No. 240/2013 Coll., on Investment Companies and Investment Funds.

Available at:

https://www.beck-online.cz/bo/chapterview-

document.seam?documentld=0z5f6mrqgezv6mrugbpwi6q\&rowlndex $=0, \quad$ accessed: $\quad 31^{\text {st }}$ August 2020.

Guidelines on key concepts of the AIFMD. ESMA/2013/611 of 13 August 2011. European Securities and Markets Authority.

Available at: https://www.esma.europa.eu/sites/default/files/library/2015/11/esma_2013_00600000_cs _tra.pdf, accessed: $31^{\text {st }}$ August 2020

Information of the Czech National Bank dated 25. 11. 2014. Asset management comparable with the management (Section 15 ZISIF).

Available at: 
https://www.cnb.cz/export/sites/cnb/cs/casto-

kladenedotazy/.galleries/stanoviska_a_odpovedi/pdf/sprava_majetku_srovnatelna_s_obhosp odarovanim_par_15_zisif.pdf, accessed: $31^{\text {st }}$ August 2020.

Information of the Czech National Bank dated 23. 4. 2018. The term "public" in the regulations on the financial market. Czech National bank.

Available at:

www.cnb.cz/export/sites/cnb/cs/casto-kladene-

dotazy/.galleries/stanoviska_a_odpovedi/pdf/pojem_verejnost.pdf, accessed: $31^{\text {st }}$ August 2020.

Ministry of Finance. Transposition of the Directive on Alternative Investment Fund Managers Consultation material of 15 July 2011.

Available at:

https://www.mfcr.cz/cs/soukromy-sektor/kapitalovy-trh/investicni-

fondy/2011/ministerstvo-financi-zverejnuje-konzulta-10026, accessed: $31^{\text {st }}$ August 2020.

Report from the Commission to the European Parliament and the Council, Brussels 10. 6. 2020, COM (2020) 232, about assessing the application and the scope of Directive 2011/61/EU of the European Parliament and of the Council on Alternative Investment Fund Managers.

Available at:

https://ec.europa.eu/transparency/regdoc/rep/1/2020/EN/COM-2020-232-F1-EN-MAIN-

PART-1.PDF, accessed: $31^{\text {st }}$ August 2020.

Regulation (EU) No. 345/2013 of the European Parliament and of the Council of 17 April 2013 on

European venture capital funds.

Available at:

https://eur-lex.europa.eu/legal-

content/EN/TXT/?qid=1599637117212\&uri=CELEX:32013R0345, accessed: $31^{\text {st }}$ August 2020.

Regulation (EU) No. 346/2013 of the European Parliament and of the Council of 17 April 2013 on European social entrepreneurship funds.

Available at:

https://eur-lex.europa.eu/legal-

content/EN/TXT/?qid=1599638667495\&uri=CELEX:32013R0346, accessed: $31^{\text {st }}$ August 2020.

Regulation (EU) 2017/1129 of the European Parliament and of the Council of 14 June 2017 on the prospectus to be published when securities are offered to the public or admitted to trading on a regulated market, and repealing Directive 2003/71/EC.

Available at:

https://eur-lex.europa.eu/legal-content/cs/TXT/?uri=CELEX\%3A32017R1129, last accessed: $31^{\text {st }}$ August 2020

\section{Internet Resources}

U. S. Securities and Exchange commission. Ponzi Scheme. United States government

Available at:

https://www.investor.gov/protect-your-investments/fraud/types-fraud/ponzi-scheme, accessed: $31^{\text {st }}$ August 2020.

KPMG. AlFMD Transposition update. KMPG. August 2014

Available at:

https://assets.kpmg/content/dam/kpmg/pdf/2014/09/aifmd-transposition-update-reportfs.pdf, accessed: $30^{\text {th }}$ August 2020.

Lists and records of regulated entities on the financial market. General overview of the number of entities as of 31 August 2020. Czech National bank

Available at:

https://apl.cnb.cz/apljerrsdad/JERRS.WEB24.SUBJECTS_COUNTS_2, last

accessed: $30^{\text {th }}$ August 2020. 